\title{
Supplementation of corn tortilla with freeze-dried jumbo squid muscle flour: physicochemical properties and microbiological stability during storage
}

\author{
Suplementación de tortilla de maíz con harina de músculo de calamar gigante liofilizado: propiedades \\ fisicoquímicas y estabilidad microbiológica durante el almacenamiento
}

Nina Gisella Heredia-Sandoval, Aaron Jonary Santiaguin-Padilla, María del Carmen Granados-Nevarez, Susana María Scheuren-Acevedo, Alma Rosa Islas-Rubio, Miguel Angel Mazorra-Manzano, Guillermina García-Sánchez and Juan Carlos Ramírez-Suarez*

Centro de Investigación en Alimentación y Desarrollo, A.C. (CIAD, A.C.), Carretera Gustavo Enrique Astiazarán Rosas \# 46, Col. La Victoria, CP. 83304, Hermosillo, Sonora.

\begin{abstract}
Corn tortilla is one of the most consumed foods in Latin America, representing a good nutrients source, although deficient in some essential amino acids. Jumbo squid (Dosdicus gigas) muscle possesses high-quality protein, useful for tortilla supplementation. Our objective was to elaborate corn tortillas supplemented with jumbo squid muscle flour (JSMF), using composite corn flours containing JSMF (2.5 and 5.0\%), to improve their nutritional quality without affecting their physicochemical/sensory properties and storage stability. Supplementation with 5\% JSMF increased $(P<0.05)$ tortilla protein level, and the essential amino acids versus the control. The $2.5 \%$ JSMF tortillas were sensory acceptable $(P \geq 0.05)$ as the control. JSMF addition showed an antimicrobial effect on mesophilic and psychrophilic bacteria; however, yeast and moulds grew beyond the permissible limit at day 5 of storage. JSMF addition did not affect $(P \geq 0.05)$ the cutting force, with tortillas tending to become harder to roll without cracking as storage elapsed. Tortilla storage stability (supplemented or not) was 3 days at $2-4{ }^{\circ} \mathrm{C}$. Results suggest the feasibility of adding JSMF to corn tortilla, improving its nutritional characteristics without markedly affecting other parameters.
\end{abstract}

Keywords: Ccorn tortilla, jumbo squid, supplementation, storage stability.

\section{RESUMEN}

La tortilla de maíz es de los alimentos más consumidos en Latinoamérica, representa una buena fuente de nutrientes, pero deficiente en algunos aminoácidos esenciales. El músculo de calamar gigante (Dosdicus gigas) posee proteína de alta calidad, útil para suplementar tortillas. Nuestro objetivo fue elaborar tortillas de maíz suplementadas con harina de músculo de calamar gigante (HMCG), utilizando harinas de maíz compuestas, conteniendo HMCG (2.5 y 5\%), para mejorar su calidad nutricional sin afectar sus propiedades fisicoquímicas/sensoriales y su estabilidad durante el almacenamiento. La suplementación con $5 \%$ HMCG incrementó $(P<0.05)$ el contenido de proteína y aminoácidos versus el control. Las tortillas con 2.5\% HMCG fueron sensorialmente aceptables $(P \geq 0.05)$ como el control. La adición de HMCG mostró un efecto antibacteriano contra bacterias mesófilas y psicrófilas; levaduras y hongos crecieron superando los límites permitidos al día 5 de almacenamiento. La suplementación no afectó $(P \geq 0.05)$ la fuerza de corte, las tortillas tendieron a ser difícilmente enrollables sin agrietarse a medida que transcurrió el almacenamiento. La estabilidad de la tortilla durante el almacenamiento (suplementada o no) fue de 3 días a $2-4^{\circ} \mathrm{C}$. Los resultados sugieren que es factible agregar HMCG a tortillas de maíz, mejorando sus características nutricionales sin afectar notablemente otros parámetros. Palabras clave: tortilla de maíz, calamar gigante, suplementación, estabilidad de almacenamiento.

\section{INTRODUCTION}

Maize (Zea mays L.), also known as corn, is an important cereal in the human diet worldwide. Corn tortilla is an ancestral unleavened bread prepared from the grounding of lime-cooking corn kernels (process called "nixtamalization") into a cohesive dough (masa) that is molded into a flat circular $(\sim 12-18 \mathrm{~cm}$ diameter, see figure 1) product that is baked into the so-called tortilla (Serna-Saldivar, 2015a). Corn tortillas are one of the most important foods consumed in Mexico, as well as other Central American countries, greatly impacting their population's nutritional status. In Mexico, the National Council for the Evaluation of Social Development Policy (CONEVAL) estimates an average annual per capita corn tortillas consumption of $56.7 \mathrm{~kg}$ in urban areas, and $79.5 \mathrm{~kg}$ in rural areas (CONEVAL, 2018). Nowadays, the corn tortilla and its chips market has expanded around the world, particularly in the USA, Asia and Europe (Cortés-Gómez et al., 2005). Although corn tortillas are considered an excellent source of calories due to their high starch content and adequate level of micronutrients as iron, zinc, and vitamins $A, D, E$ and B12 (Serna-Saldivar, 2015b), it is deficient in some essential amino acids, such as tryptophan and lysine (Martínez-Velasco et al., 2018). In protein nutrition, supplementation is the addition of a moderate quantity of quality protein with a high content of essential amino acids, to another protein source in which that amino acid is limiting, thereby improving the protein quality of the food (FAO, 1989). The nutritional value of tortillas can be upgraded by the addition of legumes and/ 


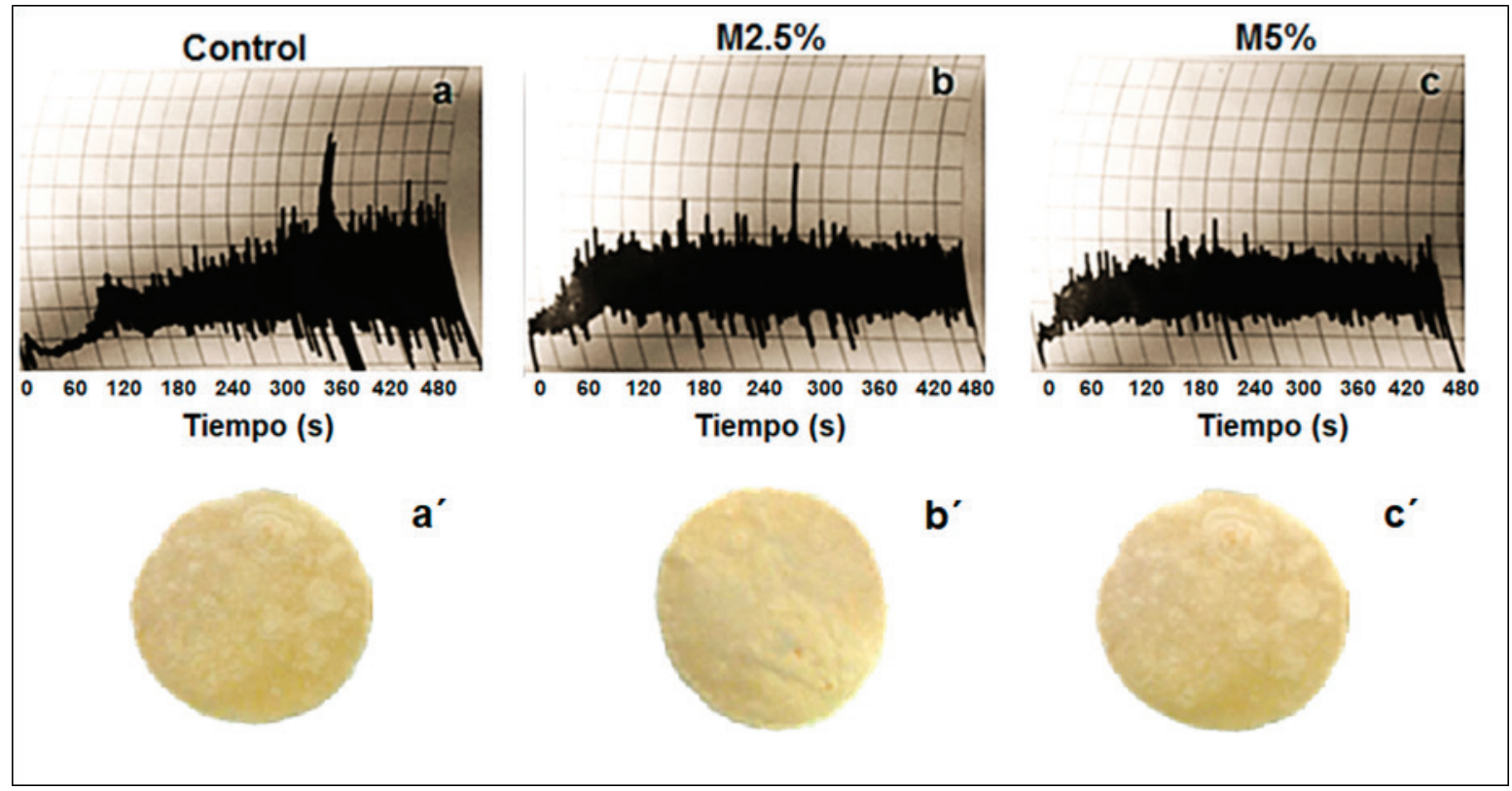

Figure 1. Mixographs and tortilla images of white corn flour and jumbo squid (Dosidicus gigas) muscle flour blends. a, a': Control (white corn flour); b, b': 97.5:2.5, white corn flour:squid flour mix (M2.5\%); and, c, c': 95:5, white corn flour:squid flour mix (M5.0\%). Figura 1. Mixogramas e imágenes de tortillas de maíz blanco y mezclas con harina de músculo de calamar gigante (Dosidicus gigas). a, a': Control (harina de maíz blanco); b, b’: 97.5:2.5, harina de maíz blanco:harina de calamar (M2.5\%); y, c, c': 95:5, harina de maíz blanco:harina de calamar (M5.0\%).

or animal products. Several studies have been conducted to improve the protein score in corn tortilla by the addition of vegetable protein such as soybean products (whole, defatted flour, protein concentrates, isolates, okara, or soymilk) (Chuck-Hernández and Serna-Saldivar, 2019), cottonseed (McPherson and Ou, 1976), germinated corn (Wang and Fields, 1978), amaranth seed (Sanchez-Marroquin et al., 1987), sorghum bran (Serna-Saldivar et al., 1988) and animal protein such as sardine (Sardina pilchardus) protein concentrate (López-Alarcón et al. 2018) and egg (Serna-Saldivar and Perez-Carrillo, 2016). However, there has been a limited use of these ingredients most probably due to the change in the tortilla sensory properties.

Jumbo squid (Dosidicus gigas) is a marine cephalopod mollusc from the Ommastrephidae family, which represents one of the five main species caught in the northwest Pacific in Mexico. This species is attractive due to its abundance, high yield, low cost, low-fat content and the whiteness of its muscle (Dihort-Garcia et al., 2011; Ramirez-Suarez et al., 2012). Nutritionally, the squid muscle is a source of high-quality, easily-digestible protein, containing all of the essential amino acids required by humans (Raya et al., 2006). Although possessing a high nutritional quality, its consumption in Mexico is low. According to surveys, factors, such as the lack of knowledge about the nutritional properties and cooking methods, have limited the consumption of squid in the national market (De La Fuente-Betancourt et al., 2008).

Therefore, the supplementation of corn products with seafood protein, a high-quality protein source, could be a good strategy to enhance their nutritional quality without affecting the physicochemical characteristics. Thus, the aim of this study was to elaborate corn tortillas supplemented with jumbo squid (D. gigas) muscle flour to improve their nutritional value, evaluating its stability during storage, physicochemical and sensory properties.

\section{MATERIALS AND METHODS \\ Raw matter and preparation of blends}

Commercial white corn flour from "MINSA" (Grupo Minsa, S.A. de C.V., Tlalnepantla, México) was used to elaborate the tortillas. Squid mantle muscle was obtained frozen from a local market. At the Seafood Laboratory of the Research Centre for Food and Development (CIAD for its initials in Spanish), the interior and exterior skins were removed. The freeze-drying technique was used to obtain a dehydrated product of the highest quality to be incorporated into tortilla production. First, mantle muscle was washed in cold water $\left(<4{ }^{\circ} \mathrm{C}\right)$, cut into $10 \times 10 \mathrm{~cm}$ pieces and frozen at $-86^{\circ} \mathrm{C}$ overnight, followed by lyophilisation using a Labconco freezedrier (Labconco Corporation. Kansas City, MO, USA). The freeze-dried sample was powdered with a food processor, eliminating any remaining unprocessed collagenous fibres. Two flour blends were prepared with 97.5:2.5 (M2.5\%) and 95:5 (M5.0\%) corn flour:squid flour ratios. All flour mixtures were adjusted to $14 \%$ moisture, according to the American Association of Cereal Chemists (AACC) methods. Corn flour was used as a control (CRL).

\section{Mixograph analysis}

The mixograph of the corn flour and flour blends was determined in duplicate following the method 54-40A (AACC, 1995) using a 30-g National Mixograph (National 
Manufacturing Co., Lincoln, NE, USA). The amount of water to add to the blends for tortilla preparation was estimated based on the mixographs. Dough consistency was suitable for processing when dough, placed in a press covered with a plastic sheet, was easily separated from the plates (Arámbula et al., 2002).

\section{Tortillas elaboration}

Tortillas were made from corn flour $(500 \mathrm{~g})$ and water (500 $\mathrm{mL}$ for CRL and $550 \mathrm{~mL}$ for the squid blends). All blends ( $C R L$ and squid added) were kneaded in a domestic kneader (Kitchen Aid, K5SS, St. Joseph, MI, USA) at low speed. Once the dough was prepared, tortillas were formed by using a manual tortilla maker, placing dough portions $(18 \mathrm{~g})$ between two plastic covers and pressing them until tortillas of approximately $13-\mathrm{cm}$ in diameter were obtained. Tortillas were cooked in an electric grill at high level $\left(\sim 200^{\circ} \mathrm{C}\right)$. Cooked tortillas were cooled and packed in polythene bags (eight per bag) to avoid moisture loss and then stored at $2-4{ }^{\circ} \mathrm{C}$. Forty tortillas per treatment were prepared.

\section{Physicochemical characterisation of tortillas}

Proximate analysis (moisture, method 44-15A; fat, method 30-25; ash, method 08-02 and protein, method 46-30.01) was performed according to the official methods of the AACC (AACC, 1995). The physical characteristics, including weight $(\mathrm{g})$, diameter $(\mathrm{cm})$ and thickness $(\mathrm{mm})$, were measured. Weight was determined using a regular balance. Diameter and thickness were measured using a Vernier caIliper. Analyses were determined in triplicate. Water activity $\left(a_{w}\right)$ was measured using a HygroPalm $a_{w}$ meter (Rotronic Instrument Corp., Huntington, NY, USA). Briefly, two tortilla layers ( $3.8 \mathrm{~cm}$ in diameter) were placed in a tray for $a_{w}$ measurement.

\section{Amino acids composition}

The effect of jumbo squid muscle flour (JSMF) addition on the protein supplemented corn tortillas was evaluated by determining the amino acid composition on previously ground and defatted tortillas, hydrolysed using $6 \mathrm{M} \mathrm{HCl}$ at 150 ${ }^{\circ} \mathrm{C}$ for $6 \mathrm{~h}$. After cooling, hydrolysed samples were buffered to $\mathrm{pH} 2.2$, then the amino acids composition was measured by HPLC using a Hewlett Packard 1100 apparatus equipped with a fluorescence detector (Hewlett Packard 1100) and an Agilent 3000-extend C18 column $(3.5 \times 150 \mathrm{~mm})$, as described previously (Vázquez-Ortiz et al., 1995).

\section{Storage stability of tortillas}

To observe the changes in the tortilla (supplemented with JSMF) stored at $2-4{ }^{\circ} \mathrm{C}$, microbiological and texture analyses were performed on the product at 0,3 and 5 days. Microbiological enumeration of the aerobic mesophilic and psychrophilic bacteria, total coliforms, Salmonella spp., Vibrio cholerae, and moulds and yeasts was undertaken according to the Official Mexican Standard NOM-187-SSA1/SCFI-2002 for dough products, tortillas, tostadas and flour, and NOM-
129-SSA1-1995 for fishery products: dry-salted, smoked, cephalopods and gastropods fresh-chilled and frozen.

Total plate count, expressed as a colony forming unit/g (CFU/g), were evaluated using plate count agar medium incubated at $35 \pm 1{ }^{\circ} \mathrm{C}$ for $48 \mathrm{~h}$ (aerobic mesophilic bacteria) and $5 \pm 2{ }^{\circ} \mathrm{C}$ for $7-10$ days (psychrophilic bacteria) respectively (Maturin and Peeler, 1998). Yeast and moulds were enumerated on potato dextrose agar medium incubated at $25{ }^{\circ} \mathrm{C}$ for 4 days (Tournas et al., 1998). Total coliforms were assessed using lauryl-tryptose broth incubated at $35 \pm 2{ }^{\circ} \mathrm{C}$, as per standard guidelines. Total coliforms were expressed as most probable number (MNP) (Feng et al., 1998). Tests were also conducted to detect the presence of bacterial pathogens, including Salmonella spp. (on lactose broth at $35-37^{\circ} \mathrm{C}$ (Andrews and Hammack, 1998) and V. cholerae (on alkaline peptone water at $27-35^{\circ} \mathrm{C}$ for $24 \mathrm{~h}$ and then on thiosulphate-citrate-bile salts-sucrose agar at $35-27^{\circ} \mathrm{C}$ for $24 \mathrm{~h}$ ).

Moisture, texture and rollability were measured on the tortillas during storage. The moisture content (method 44-15A) was assessed according to the AACC (1995). Texture analysis was performed by evaluating the cutting force using a TA-XT2 texture analyser (Texture Technologies Corp., Godalming, Surrey, UK). Briefly, the tortilla was placed on the platform and then penetrated by the probe moving at $2 \mathrm{~mm} / \mathrm{s}$. Rollability was tested by the subjective method reported by Bedolla (Bedolla, 1983). First, tortillas were cut into four strips, and then each strip was wrapped around a timber rod of 2 $\mathrm{cm}$ in diameter. The rupture degree was determined using his subjective scale of 1 to 5 . A score of 1 represents a $100 \%$ tortilla breakage or torn tortilla; a score 3 indicates a partially ruptured tortilla or $50 \%$ breakage in tortilla structure; and a score of 5 indicates an unruptured tortilla, the best rollability. Four tortillas were measured per treatment.

\section{Sensory evaluation}

A panel of 80 untrained individuals evaluated three sensory attributes of the tortilla (aroma, taste and general acceptability) on the day of its production (day 0) only. Responses were scored on the following hedonic scale: $1=$ dislike extremely; 3 = dislike; 5 = neither like nor dislike; 7 = like; 9 = like extremely (Lawless and Heymann, 2010).

\section{Statistical analysis}

For the physicochemical properties of the tortillas, a $3 \times 3$ factorial experiment arranged in a completely randomised design was used, considering the storage time $(0$, 3 and 5 days) as factor 1 and three treatments (CRL, M2.5\% and $\mathrm{M} 5.0 \%$ ) as factor 2. For sensory evaluation, repeated measures ANOVA were used for detailed analyses. Multiple comparisons of the means were achieved by using the TukeyKramer test when interactions were not significant. Statistical analysis software NCSS (version 2007) was used. Values with a $P<0.05$ were considered statistically significant. 


\section{RESULTS AND DISCUSSION}

\section{Mixograph analysis}

Figure 1 shows the dough resistance during mixing for each treatment. Results showed that the mixing tolerance (bandwidth after peak) decreased with increasing level of JSMF in the blends. It can be observed that as JSMF was added to corn flour, the dough retained its resistance throughout the blending time but was smaller than the CRL. The amount of water to be added for best dough consistency was determined from the mixographs. Thus, the best dough consistency for CRL (maize flour) was achieved by adding $100 \%$ of water (w/v, flour:water), while an additional 10\% (w/v) of water was necessary for samples supplemented with JSMF, probably because of the increase in the water absorption capacity, considering the blends contained higher protein than the CRL (Table 1) (Adeyeye et al., 2017; Kongo-Dia-Moukala and Zhang, 2011). However, JSMF addition decreased the hydration time compared with CRL. According to the mixographs, the kneading time was 3 min for the control and 3 $\min 30 \mathrm{~s}$ for the squid mixtures.

Table 1. Proximate composition and water activity (aw) of corn tortillas supplemented with 2.5 (M2.5\%) and 5.0\% (M5.0\%) of jumbo squid muscle flour (Dosidicus gigas).

Tabla 1. Composición proximal y actividad de agua $\left(a_{w}\right)$ de tortillas de maíz suplementadas con 2.5 (M2.5\%) y 5.0\% (M5.0\%) de harina de músculo de calamar gigante (Dosidicus gigas).

\begin{tabular}{lccccc}
\hline Sample & Moisture & Protein & Fat & Ash & $a_{w}$ \\
\hline Control & $41.5 \pm 0.9$ & $8.6 \pm 0.0^{\mathrm{a}}$ & $3.3 \pm 0.4$ & $1.2 \pm 0.1^{\mathrm{a}}$ & $0.930 \pm 0.0$ \\
M2.5\% & $40.1 \pm 0.4$ & $10.4 \pm 0.4^{\mathrm{b}}$ & $3.4 \pm 0.1$ & $1.4 \pm 0.2^{\mathrm{a}}$ & $0.935 \pm 0.0$ \\
M5.0\% & $41.8 \pm 0.4$ & $12.6 \pm 0.2^{\mathrm{c}}$ & $3.4 \pm 0.1$ & $1.7 \pm 0.1^{\mathrm{b}}$ & $0.950 \pm 0.0$ \\
\hline
\end{tabular}

Different letters in the same column are significantly different $(p<0.05)$.

\section{Physicochemical analysis of tortillas}

The tortillas supplemented with JSMF (Figure 1) had a similar appearance to the control, although no evaluations were performed to determine differences in parameters, such as colour, appearance or texture. All tortillas were standardised to a diameter, thickness and weight of $13 \mathrm{~cm}$, $2 \pm 0.2 \mathrm{~mm}$ and $22 \pm 2 \mathrm{~g}$, respectively, to ensure the analysed samples were homogenous. The proximate composition of tortillas is shown in Table 1. Their moisture content showed no significant difference $(P \geq 0.05)$ between the treatments and $C R L$, all fluctuating between 40 and $42 \%$. The moisture content was in the expected range for maize tortillas (34-48\%; Hernández-Uribe et al., 2007; Rendón-Villalobos et al., 2009). Similarly, tortillas fat content (3.34-3.42\%) was not affected $(P \geq 0.05)$ by JSMF addition, due to the low-fat content $(<1 \%)$ present in the squid muscle (Ramirez-Suarez et al., 2008). Tortilla ash and protein contents increased $(P<0.05)$ with supplementation of JSMF at both levels. Interestingly, the addition of JSMF significantly increased $(P<0.05)$ the tortilla protein content by 20 and $45 \%$ for M2.5 and M5.0\%, respectively. These results highlight the great impact that JSMF addition has over the nutritional quality of the maize tortillas. Similarly, tortilla ash content also increased $(P<$ 0.05 ) due to JSMF addition. Similar behaviour was found by Lopez-Alarcón et al. (2018) when adding sardine protein concentrate to this type of tortillas, increasing their protein and ash contents. There were no significant changes in the $a_{w}$ $(P \geq 0.05)$ between treatments, with a mean of $0.94 a_{w}$ among them. Relatively higher $a_{w}$ values (0.96) were found by TellezGiron et al. (1988) in commercial corn tortillas but the storage stability was comparable between both studies, as discussed below in section 3.5 .

\section{Amino acid composition}

Although corn nixtamalisation is conducted to improve its nutritional quality over the unprocessed grain, the tortilla made from this flour is deficient in essential amino acids, such as lysine and tryptophan (Martínez-Velasco et al., 2018). Figure 2 shows the amino acid composition of maize tortillas added with different levels of JSMF. As expected, with JSMF addition, the majority of essential and non-essential amino acid contents increased proportionally. Interestingly, lysine, one of the deficient essential amino acids in corn flour, increased from $2.8 \mathrm{mg} / \mathrm{g}$ in $\mathrm{M} 2.5 \%$ to $5.8 \mathrm{mg} / \mathrm{g}$ in $\mathrm{M} 5.0 \%$ maize tortillas. Methionine is another essential amino acid that was greatly improved in tortillas with an increase $(P<$ 0.05 ) of $175 \%$ when $5.0 \%$ JSMF was used. It is evident that jumbo squid muscle proteins, possessing high nutritional quality, improved the nutritional quality of the corn tortillas, as reflected by their increased essential amino acid content.

\section{Sensory evaluation}

Figure 3 reveals the panellists' scores for the sensory attributes (aroma, taste and overall acceptability) of corn tortillas supplemented with JSMF. Aroma scores were similar between the tortillas supplemented with JSMF (M2.5\% and $\mathrm{M} 5.0 \%)$, although lower $(P<0.05)$ than the control. As expected, and due to the nature of the material used for supplementation (JSMF), the untrained panellists perceived a "fishy" aroma, which contributed to the results. However, the supplemented tortillas scored above the range of "neither like nor dislike". Notably, the addition of JSMF to tortillas did not affect the taste attribute scores, presenting similar scores for $\mathrm{M} 2.5 \% \mathrm{M} 5.0 \%$ and CRL $(P \geq 0.05)$. Moreover, overall accep-

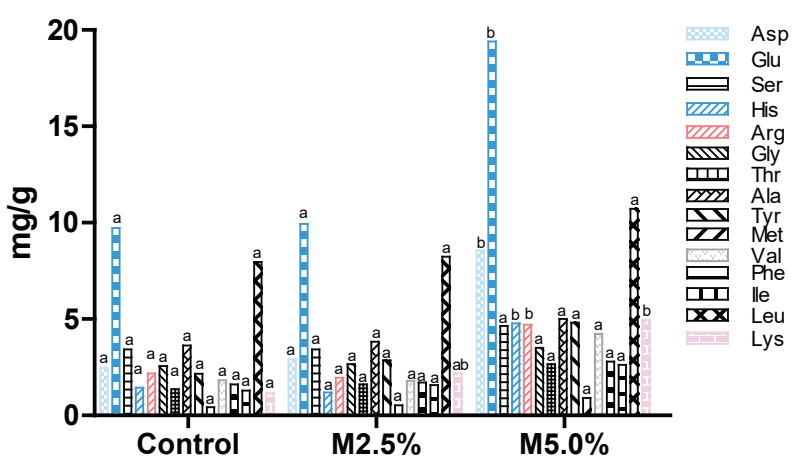

Figure 2. Amino acid content of corn tortillas supplemented with 2.5 (M2.5\%) and 5.0\% (M5.0\%) jumbo squid muscle flour (Dosidicus gigas). Figura 2. Contenido de aminoácidos de tortillas de maíz suplementadas con 2.5 (M2.5\%) y 5.0\% (M5.0\%) de harina de músculo de calamar gigante (Dosidicus gigas). 


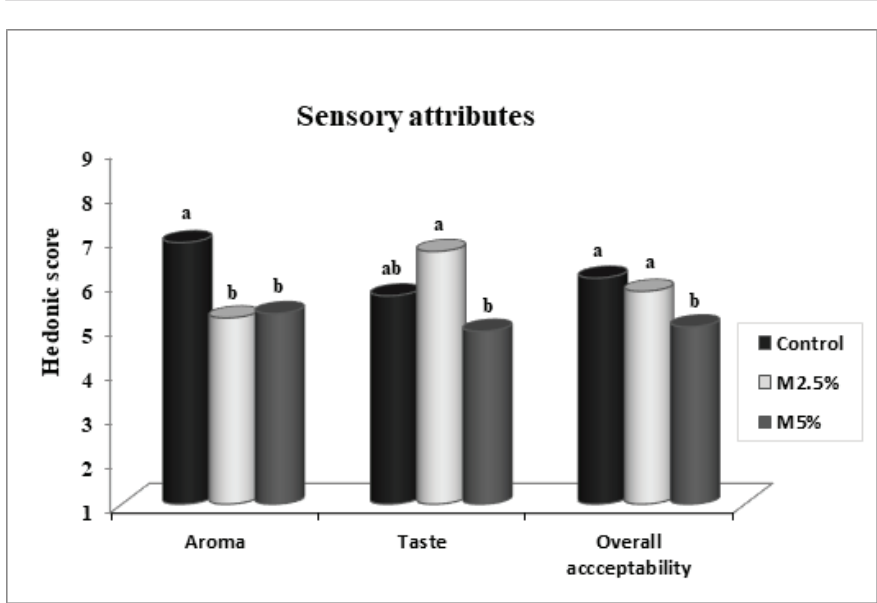

Figure 3. Sensory attributes of corn tortillas supplemented with 2.5 (M2.5\%) and 5.0\% (M5.0\%) jumbo squid muscle flour (Dosidicus gigas). $n=$ 80.

Figura 3. Atributos sensoriales de tortillas de maíz suplementadas con 2.5 (M2.5\%) y 5.0\% (M5.0\%) de harina de músculo de calamar gigante (Dosidicus gigas). $n=80$.

tability of the tortillas supplemented with JSMF, particularly M2.5\% did not differ $(P \geq 0.05)$ from the control. However, tortillas supplemented with $5.0 \% \mathrm{JSMF}$, despite scoring the lowest $(P<0.05)$ acceptability value, were still acceptable ("neither like nor dislike").

It is reasonable to suggest that the attributes that scored lower for the supplemented tortillas than the control is because the panellists' are unfamiliar with this type of product. No other tortillas supplemented with JSMF have been introduced into the regional market, in which no consumption of seafood products prevails.

\section{Storage stability of tortillas}

Changes in the microbiological quality of food influences the product shelf-life and can have an effect on consumer's health. Corn tortillas are mostly consumed when freshly-made. However, due to its moisture and high $a_{w^{\prime}}$ this product presents a short shelf-life. Proposals to increase its shelf-life include storage at refrigerated temperatures either alone or in combination with antimicrobial agents (Martínez Flores et al., 2004). The microbiological results of tortillas stored at $2-4^{\circ} \mathrm{C}$ for 5 days are shown in Table 2 . Interestingly, the addition of JSMF to the formulation affected the growth of mesophilic and psychrophilic bacteria in tortillas, especially at day 5 of storage, with values remaining under the maximum permissible level of $1 \times 10^{4} \mathrm{CFU} / \mathrm{g}$ (NOM-147-SSA1-1996). A previous in vitro analysis of crude extracts from two different squid species tissues (Loligo duvauceli and Doryteuthis sibogae) indicated a potential antimicrobial effect (Barwin Vino et al., 2014), which could explain the microbiological effect afforded by the addition of JSMF to corn tortillas observed in the present study.

One of the main obstacles to storing maize tortillas is mould growth, which can be delayed but not prevented (McDonough et al., 2015). In this regard, all tortillas (CRL, M2.5\%, M5.0\%) presented permissible levels of mould and yeast (300
Table 2. Microbiological analysis of corn tortillas supplemented with 2.5 (M2.5\%) and 5.0\% (M5.0\%) jumbo squid (Dosidicus gigas) muscle flour, stored at $2-4{ }^{\circ} \mathrm{C}$ for 5 days.

Tabla 2. Análisis microbiológico de tortillas de maíz suplementadas con 2.5 (M2.5\%) y 5.0\% (M5.0\%) de harina de músculo de calamar gigante (Dosidicus gigas), almacenadas a $2-4{ }^{\circ} \mathrm{C}$ por 5 días.

\begin{tabular}{|c|c|c|c|}
\hline \multirow[b]{2}{*}{ Sample } & \multicolumn{3}{|c|}{ Storage time } \\
\hline & Day 0 & Day 3 & Day 5 \\
\hline & \multicolumn{3}{|c|}{ Aerobic Mesophilic Bacteria (UFC/g) } \\
\hline Control & 600 & $<100$ & 308,000 \\
\hline M2.5\% & 400 & $<100$ & 300 \\
\hline \multirow[t]{2}{*}{ M5.0\% } & 300 & $<100$ & 300 \\
\hline & \multicolumn{3}{|c|}{ Aerobic Psychrophilic Bacteria (UFC/g) } \\
\hline Control & $<100$ & $<100$ & 248,000 \\
\hline $\mathrm{M} 2.5 \%$ & $<100$ & $<100$ & 200 \\
\hline \multirow[t]{2}{*}{ M5.0\% } & $<100$ & $<100$ & $<100$ \\
\hline & \multicolumn{3}{|c|}{ Yeasts and Moulds (UFC/g) } \\
\hline Control & $<100$ & $<100$ & 2,200 \\
\hline M2.5\% & $<100$ & $<100$ & 2,200 \\
\hline \multirow[t]{2}{*}{ M5.0\% } & $<100$ & $<100$ & 107,000 \\
\hline & \multicolumn{3}{|c|}{ Total Coliforms (MPN/g) } \\
\hline Control & $<3$ & $<3$ & $<3$ \\
\hline M2.5\% & $<3$ & $<3$ & $<3$ \\
\hline \multirow[t]{2}{*}{ M5.0\% } & $<3$ & $<3$ & $<3$ \\
\hline & \multicolumn{3}{|c|}{ Salmonella spp. (presence/25g) } \\
\hline Control & Absence & ND & Absence \\
\hline $\mathrm{M} 2.5 \%$ & Absence & ND & Absence \\
\hline \multirow[t]{2}{*}{ M5.0\% } & Absence & ND & Absence \\
\hline & \multicolumn{3}{|c|}{ Vibrio cholerae (presence/50 g) } \\
\hline Control & Absence & ND & Absence \\
\hline M2.5\% & Absence & ND & Absence \\
\hline M5.0\% & Absence & ND & Absence \\
\hline
\end{tabular}

ND: not detected

CFU/g, based on NOM-147-SSA1-1996) up to storage day 3. Foodborne pathogens, such as total coliform counts, remained $<3$ MPN in all samples and storage days, a value below the permissible limits, indicating a good hygienic control in the processing of tortillas (Feng et al., 1998). Besides, Salmonella spp. and $V$. cholera were absent in all samples during the study.

In addition to the microbiological control, it is also difficult to retain the original texture and sensory characteristics of tortilla after its elaboration. As the storage progresses, the tortilla texture becomes firmer and more rigid, which in turn, affect its rollability (Suhendro et al., 1998).

Table 3 shows the textural properties (cutting force and rollability) measured on tortillas stored at $2-4{ }^{\circ} \mathrm{C}$ for 5 days. No differences $(P \geq 0.05)$ in cutting force were observed among the treatments on each storage day. In other words, the addition of JSMF did not affect the resistance strength of tortillas. However, when comparing each treatment throughout the storage, significant differences $(P<0.05)$ were obser- 
Table 3. Texture properties of corn tortillas supplemented with 2.5 (M2.5\%) and $5.0 \%$ (M5.0\%) jumbo squid flour (Dosidicus gigas), stored at $2-4{ }^{\circ} \mathrm{C}$ for 5 days.

Tabla 3. Textura de tortillas de maíz suplementadas con 2.5 (M2.5\%) y $5.0 \%$ (M5.0\%) de harina de músculo de calamar gigante (Dosidicus gigas), almacenadas a $2-4^{\circ} \mathrm{C}$ por 5 días.

\begin{tabular}{|c|c|c|c|c|c|c|}
\hline \multirow{2}{*}{ Treatment } & \multicolumn{3}{|c|}{ Storage time (days) } & \multicolumn{3}{|c|}{$P$-value } \\
\hline & 0 & 3 & 5 & $T$ & $s$ & $T \times S$ \\
\hline & \multicolumn{3}{|c|}{ Cutting force $(\mathrm{N}) \pm S D^{*}$} & 0.37 & 0.00 & 0.43 \\
\hline Control & $3.6 \pm 0.7$ & $4.8 \pm 1.2$ & $10.9 \pm 2.1$ & & & \\
\hline M2.5\% & $4.0 \pm 0.4$ & $6.8 \pm 0.7$ & $10.7 \pm 1.1$ & & & \\
\hline \multirow[t]{2}{*}{ M5.0\% } & $3.3 \pm 0.1$ & $5.7 \pm 0.5$ & $11.1 \pm 1.5$ & & & \\
\hline & \multicolumn{3}{|c|}{ Rollability $\pm S D^{* *}$} & 0.02 & 0.00 & 0.00 \\
\hline Control & $4.9 \pm 0.3$ & $4.0 \pm 0.6$ & $1.8 \pm 0.7$ & & & \\
\hline M2.5\% & $4.1 \pm 0.9$ & $3.2 \pm 0.7$ & $2.3 \pm 0.7$ & & & \\
\hline M5.0\% & $4.5 \pm 0.7$ & $2.8 \pm 0.9$ & $2.1 \pm 0.8$ & & & \\
\hline
\end{tabular}

$T:$ Principal effect in treatments; $S$ : Principal effect in storage time; $T \times S$ : Interaction effect between $T$ and $S$. Values with $P<0.05$ are significantly different. Data represent mean \pm standard deviation (SD). .* Triplicate means. ** Quadruplicate means.

ved, and it became increasingly harder to cut the tortillas. This behaviour can be related to the starch retrogradation since no major changes were noticed in the moisture content of tortillas stored for 5 days (results not shown) (Alvarez-Ramirez et al., 2018). It is known that starch retrogradation causes corn tortillas to stale rapidly after elaboration (Hernández-Uribe et al., 2007). Regarding the corn tortilla rollability, although a significant $(P<0.05)$ interaction of the main effects was found (Table 3), no matter the treatment, the tortillas tended to become harder to roll without cracking as the storage elapsed. Nevertheless, similar values were found among treatments.

Based on the microbiological (yeast and moulds) and texture results, under the conditions of the study, all the tortillas (CRL, M2.5\%, M5.0\%) lasted up to 3 days when stored at $2-4^{\circ} \mathrm{C}$. Results demonstrate that the addition of JSMF did not affect most of the physical characteristics of corn tortillas.

\section{CONCLUSION}

Overall results suggest the feasibility of adding JSMF to corn tortillas for improving the nutritional characteristics, without affecting other parameters. However, more research is needed to improve storage stability. It can also be concluded that this product, with its particular fishy taste, can be introduced into other regions where consumers frequently consume fish products, considering that the addition of JSMF conferred a delicate "fishy" taste to the product.

\section{CONFLICT OF INTEREST STATEMENT}

None declared

\section{FUNDING}

This research did not receive any specific grant from funding agencies in the public, commercial, or not-for-profit sectors.

\section{REFERENCES}

AACC. 1995. Approved methods of the American Association of Cereal Chemists. AACC, St. Paul, MN.

Adeyeye, S. A. O., Adebayo-Oyetoro, A. O. y Omoniyi, S. A. 2017. Quality and sensory properties of maize flour cookies enriched with soy protein isolate. Cogent Food \& Agriculture, 3: 1278827.

Alvarez-Ramirez, J., Garcia-Diaz, S., Vernon-Carter, E. J. y BelloPerez, L. A. 2018. A novel, simple, economic and effective method for retarding maize tortilla staling. Journal of the Science of Food and Agriculture. 98: 4403-4410.

Andrews, W. H. y Hammack, T. S. 1998. Salmonella. En: Bacteriological Analytical Manual. AOAC International, Gaithersburg, MD.

Arámbula, V. G., González-Hernández, J., Moreno, M. E. y Ordorica, F. C. A. 2002. Characteristics of Tortillas Prepared from Dry Extruded Masa Flour Added with Maize Pericarp. Journal of Food Science. 67: 1444-1448.

Barwin Vino, A., Shanmugam, V. y Shanmugam, A. 2014. Antimicrobial activity of methanolic extract and fractionated polysaccharide from Loligo duvauceli Orbingy 1848 and Doryteuthis sibogae Adam 1954 on human pathogenic microorganisms. African Journal of Microbiology Research. 8: $230-236$.

Bedolla, S. 1983. Development and characterization of instant tortilla flours from sorghum and corn by infrared cooking (micronizing) and extrusion cooking. Ph. D. Dissertation, Texas, A\&M University, College Station. TX, USA.

Chuck Hernández, C. E. y Serna-Saldivar, S.O. 2019. Capítulor 25Soybean-Fortified Nixtamalized Corn Tortillas and Related Products. En: Flour and Breads and their Fortification in Health and Disease Prevention. V. R. Preedy y R. R. Watson (eds.) pp. 319-332. Academic Press.

Coneval (2018). Evolución de la canasta alimentaria. Consulta del valor de las líneas de bienestar. https://www.coneval. org.mx/Medicion/MP/Paginas/Lineas-de-bienestar-ycanasta-basica.aspx

Cortés-Gómez, A., Martı冈n-Martı冈nez, E. S., Martı冈nez-Bustos, F.y Vázquez-Carrillo, G. M. 2005. Tortillas of blue maize (Zea mays L.) prepared by a fractionated process of nixtamalization: analysis using response surface methodology. Journal of Food Engineering. 66: 273-281.

De La Fuente-Betancourt, G., García-Carreño, F., Navarrete del Toro, M. A., Pacheco-Aguilar, R. y Córdova-Murueta, J. H. 2008. Effect of storage at $0{ }^{\circ} \mathrm{C}$ on mantle proteins and functional properties of jumbo squid. International Journal of Food Science \& Technology. 43: 1263-1270.

Dihort-Garcia, G., Ocano-Higuera, V. M., Ezquerra-Brauer, J. M., Lugo-Sanchez, M. E., Pacheco-Aguilar, R., Barrales-Heredia, S. M. y Marquez-Rios, E. 2011. Producción y evaluación funcional de un concentrado proteico de calamar gigante (Dosidicus gigas) obtenido mediante disolución alcalina Production and functional evaluation of a protein concentrate from giant squid (Dosidicus gigas) obtained by alkaline dissolution. CyTA - Journal of Food. 9: 171-179.

FAO. 1989. General Guidelines for the Utilization of Vegetable Protein Products (VPP) in Foods. En: CAC/GL 4-1989 (C. A. I. F. Standards, ed.). http://www.fao.org/fao-whocodexalimentarius/sh-proxy/it/?lnk=1\&url=https\%253A\%2 52F\%252Fworkspace.fao.org\%252Fsites\%252Fcodex\%252 FStandards\%252FCAC\%2BGL\%2B4-1989\%252FCXG_004e. pdf. 
Feng, P., Weagant, S. D. y Grant, M. A. 1998. Enumeration of Escherichia coli and the Coliform Bacteria. En: Bacteriological Analytical Manual. AOAC International, Gaithersburg, MD.

Hernández-Uribe, J. P., Agama-Acevedo, E., Islas-Hernández, J. J., Tovar, J. y Bello-Pérez, L. A. 2007. Chemical composition and in vitro starch digestibility of pigmented corn tortilla. Journal of the Science of Food and Agriculture. 87: 24822487.

Kongo-Dia-Moukala, J. U. y Zhang, H. 2011. Defatted Corn Protein Extraction: Optimization by Response Surface Methodology and Functional Properties. American Journal of Food Technology. 6: 870-881.

Lawless, H. T. y Heymann, H. 2010. Acceptance Testing. En: Sensory Evaluation of Food, pp. 325-344. Springer-Verlag New York.

López-Alarcón, M., Montalvo-Velarde, I., Bernal-Gracida, L. y Barbosa-Cortés, M. L. 2018. Maíz nixtamalizado suplementado con un concentrado de proteínas de sardina para mejorar el valor biológico de las tortillas. Gaceta Médica de México. 154: 327-334.

Martínez-Velasco, A., Alvarez-Ramirez, J., Rodríguez-Huezo, E., Meraz-Rodríguez, M., Vernon-Carter, E. J. y Lobato-Calleros, C. 2018. Effect of the preparation method and storage time on the in vitro protein digestibility of maize tortillas. Journal of Cereal Science. 84: 7-12.

Martínez Flores, H. E., Gaytán Martínez, M., Figueroa Cárdenas, J. d. D., Martínez Bustos, F., Reyes Vega, M. d. I. L. y Rodríguez Vidal, A. 2004. Effect of Some Preservatives on Shelf-life of Corn Tortillas Obtained From Extruded Masa. Agrociencia. 38: 285-292.

Maturin, L. J. y Peeler, J. T. 1998. Aerobic plate count. En: Bacteriological Analytical Manual. AOAC International, Gaithersburg, MD.

McPherson, C. M. y Ou, S. Y. L. 1976. Evaluation of corn tortillas supplemented with cottonseed flour. Journal of Food Science. 41(6): 1301-1304.

McDonough, C. M., Alviola, J. N. y Waniska, R. D. 2015. Capítulo 9 - Preservatives: Extending Shelf Life and Shelf Stability. En: Tortillas (L. W. Rooney y S. O. Serna-Saldivar, eds.), pp. 195200. AACC International Press.

NOM-147-SSA1-1996. 1996. Bienes y Servicios. Cereales y sus Productos. Harinas de cereales, semolas o semolinas. Alimentos a base de cereales, de semillas comestibles, harinas, semolas o semolinas o sus mezclas. Productos de panificación. Disposiciones y especificaciones sanitarias y nutrimentales.

NOM-129-SSA1-1995. 1997. Bienes y servicios. Productos de la pesca: secos-salados, ahumados, moluscos cefalópodos y gasterópodos frescos-refrigerados y congelados. Disposiciones y especificaciones sanitarias. http://www. salud.gob.mx/unidades/cdi/nom/129ssa15.html.

NOM-187-SSA1/SCFI-2002. 2003. Productos y servicios. Masa, tortillas, tostadas y harinas preparadas para su elaboración y establecimientos donde se procesan. Especificaciones sanitarias. Información comercial.Métodos de prueba.http:// www.salud.gob.mx/unidades/cdi/nom/187ssa1scfi02.html.
Ramirez-Suarez, J. C., Ibarra-León, L. R., Pacheco-Aguilar, R., Lugo-Sánchez, M. E., García-Sánchez, G. y Carvallo-Ruiz, G. 2008. Physicochemical and functional changes in jumbo squid (Dosidicus gigas) mantle muscle during ice storage. Food Chemistry. 111: 586-591.

Ramirez-Suarez, J. C., Islas-Rubio, A. R., Montoya-Ballesteros, L. C., Granados-Nevarez, M. C., Vázquez-Lara, F., Pacheco-Aguilar, R. y Lugo-Sánchez, M. E. 2012. Effect of lyophilized jumbo squid (Dosidicus gigas) fin and mantle muscle on dough properties and bread baking performance of commercial wheat flour. CyTA - Journal of Food. 10: 57-62.

Raya, M. C. L., García, J. I. U., Zavala, C. A. S., Mata, M. Á. C. y Morales, L. F. B. 2006. Diagnóstico del consumo del calamar gigante en México y en Sonora. Economía Sociedad y Territorio. VI: 535-560.

Rendón-Villalobos, R., Agama-Acevedo, E., Osorio-Diaz, P., Tovar, J. y Bello-Pérez, L. A. 2009. Proximal composition and in vitro starch digestibility in flaxseed-added corn tortilla. Journal of the Science of Food and Agriculture. 89: 537-541.

Sanchez-Marroquin, A., Feria-Morales, A., Maya, S. y RamosMoreno, V. 1987. Processing, nutritional quality and sensory evaluation of amaranth enriched corn tortilla. Journal of Food Science. 52:1611-1614.

Serna-Saldívar, S. O., Canett, R., Vargas, J., González, M., Bedolla, S. y Medina, C. 1988. Effect of value of maize and decorticated sorghum tortillas produced by extrusion-cooking. Cereal Chemistry. 65: 44-48.

Serna-Saldivar, S. O. 2015a. Nutritional and nutraceutical features of regular and protein fortified corn tortillas. En: Bread and its Fortification: Nutrition and Health Benefits. C. M. Rosell, J. Bajerska, A. F. El Sheikha (eds.), pp. 322-354. CRC Press. Boca Raton.

Serna-Saldivar, S. O. 2015b. Nutrition and fortification of corn and wheat tortillas. En: Tortillas. L. W. Rooney, S. O. SernaSaldivar (eds), pp. 29-63. AACC International Press.

Serna-Saldivar, S. O. y Perez-Carrillo, E. 2016. Maize. En: Encyclopedia of Food and Health. B. Caballero, P. Finglas y F.Toldra (eds.), pp. 601-609. Academic Press. Oxford.

Suhendro, E. L., Almeida-Dominguez, H. D., Rooney, L. W. y Waniska, R. D. 1998. Objective Rollability Method for Corn Tortilla Texture Measurement. Cereal Chemistry. 75: 320-324.

Tellez-Giron, A., Acuff, G. R., Vanderzant, C., Rooney, L. W. y Waniska, R. D. 1988. Microbiological Characteristics and Shelf Life of Corn Tortillas with and without Antimicrobial Agents. Journal of Food Protection. 51: 945-948.

Tournas, V., Stack, M. E., Mislivec, P. B., Koch, H. A. y Bandler, R. 1998. Yeasts, Molds and Mycotoxins. En: Bacteriological Analytical Manual. AOAC International, Gaithersburg, MD.

Vázquez-Ortiz, F. A., Caire, G., Higuera-Ciapara, I. y Hernández, G. 1995. High Performance Liquid Chromatographic Determination of Free Amino Acids in Shrimp. Journal of Liquid Chromatography. 18: 2059-2068.

Wang, D.Y.Y. y Fields, M. L. 1978. Enrichment of home-prepared tortillas made from germinated corn. Journal of Food Science. 43(5): 1630-1631. 